\title{
Abstracts of Articles
}

\section{"Cultural Chameleons: Portuguese Eurasian Strategies for Survival in Post-colonial Malaysia" by MARGARET SARKISSIAN}

This article documents the shifting identity over time of a single Malaysian ethnic minority, the Portuguese Eurasian community of Malacca. Through a close examination of three pivotal historical moments (1952,1969, and 1995), it shows how cultural phenomena (in this case, music and dance) play key roles in the projection of new public images.

\section{"Indigenous People, The State and Ethnogenesis: A Study of the Communal Asso- ciations of the 'Dayak' Communities in Sarawak, Malaysia" by TAN CHEE-BENG}

This article describes the communal associations of the "Dayak" communities in Sarawak, and their functions of relating to the state and articulating local interests of the indigenous minorities. The significance of communal associations to the ethnogenesis of indigenous peoples is considered as well. Overall, communal associations are useful for projecting the presence of indigenous peoples in a communally stratified nation-state.

"Masonic Myths and Revolutionary Feats in Negros Occidental" by FILOMENO V. AGUILAR, Jr.

The popular interpretations of the end of Spanish colonial rule in Negros Occidental, Philippines, are closely intertwined with Masonic-related imageries that suffused the colony's export-oriented economy in general and the province's sugar industry in particular. Through an investigation of folklore as a bearer of historical consciousness, it is argued that the elite-led one-day uprising that led to Spain's downfall in the province contained a mythical dimension that helped solidify the dominance of the local sugar planter class.

“The Agricultural Bank of the Philippine Government, 1908-1916" by YOSHIKO NAGANO

This study of the Agricultural Bank of the Philippine Government, which was established in 1908 to provide agricultural loans to local farmers, describes the background of bank, focusing on the active role of the local elite. Then, it discusses to what extent the bank served the needs of landlords, and why it stopped operations in 1916, facing a shortage of capital.

\section{“The Japanese Fisheries Based in Singapore, 1892-1945" by HIROSHI SHIMIZU}

This paper examines the main factors behind the rise and decline of the Japanese fisheries based in Singapore before the Pacific War, and shows that, as the fisheries 
contributed greatly to the Singapore economy, they did not constitute a foreign economic enclave in the British colony. It also describes how the Japanese and local fishermen conducted fisheries during the period from 1942 to 1945 , and argues that the legacy of the Japanese fisheries outlived the Japanese occupation.

"The Holy Man in the History of Thailand and Laos" by CONSTANCE M. WILSON

Holy men were respected leaders in early Thai and Lao society. As Thai society became more complex, traditional holy men disappeared, to be replaced by modern charismatic monks. But, in Southern Laos and the Khorat Plateau, holy men found a new role as leaders of protest movements.

"'International Orphans' - The Chinese in Thalland During World War II" by E. BRUCE REYNOLDS

An examination of Japanese efforts to gain the cooperation of the intrinsically hostile, but economically vital Overseas Chinese community in Thailand, this article also focuses on the impact of the Japanese wartime presence on the troubled relationship between the Chinese and the Thai authorities, and the success of Chinese entrepreneurs in turning adversity to advantage. 